\title{
Analysis of occurrence of bacteraemia with pathogens from gastrointestinal tract in patients fed parenterally and enterally in the intensive care unit
}

\author{
Marlena Jakubczyk ${ }^{1}$, Aleksandra Różowicz ${ }^{1}$ Katarzyna Spychalska ${ }^{1}$, Beata Nakonowska ${ }^{2}$, Kinga Kupczyk ${ }^{1}$, \\ Krzysztof Kusza ${ }^{1,3}$ \\ ${ }^{1}$ Department and Clinic of Anaesthesiology and Intensive Care, Collegium Medicum in Bydgoszcz, Nicolaus Copernicus \\ University in Torun, Poland \\ 2Department and Institution of Microbiology, Collegium Medicum in Bydgoszcz, Nicolaus Copernicus University in Torun, Poland \\ ${ }^{3}$ Department of Anaesthesiology and Intensive Care, Poznan University of Medical Science, Poznan, Poland
}

Key words: intensive care, enteral nutrition, parenteral nutrition, bacteraemia, translocation.

Address for correspondence: Marlena Jakubczyk MD, Department of Anaesthesiology and Intensive Care, University Hospital No. 1, 9 M. Skłodowskiej-Curie St, 85-094 Bydgoszcz, Poland, phone/fax: +48 5258547 50, e-mail: marljakz@wp.pl

\begin{abstract}
Introduction: Bacterial translocation is a migration of microorganisms and their toxins from the intestinal lumen to the mesenteric lymph nodes, blood, and abdominal organs. It can lead to local inflammatory response and a potential increase in intestinal permeability leading to systemic infections and multiple organ failure. Enteral nutrition stimulates gastrointestinal motility, increases blood flow, and improves the integration of the intestinal barrier.

Aim: The impact of enteral (EN) and parenteral (PN) nutrition on occurrence of bacteraemia caused by pathogens from the gastrointestinal tract.

Material and methods: It was a retrospective analysis of medical documentation of 254 patients. Microbiological tests were analysed, assessing the presence of bacteraemia or sepsis pathogens from the gastrointestinal tract. In 52 patients gastrointestinal pathogens in blood were found: 29 patients were fed enterally (I group - EN and EN + PN) and 23 only parenterally (II group - PN).

Results: The mean length of stay in hospital until the occurrence of bacteraemia in group I was 14, and in group II it was 13 days. Mean time without EN was 4 days (first group) and 12 days (second group). Time of stay in ICU and mortality in the group of patients fed parenterally was observed: group I -25 days, mortality $34 \%$; group II -37 days, mortality $56 \%$. In the analysed group the EN and the length of the absence of this kind of feeding did not affect the occurrence of bacteraemia by gastrointestinal pathogens.

Conclusions: However, patients fed only parenterally who had bacteraemia required a longer stay in the ICU and had a higher rate of mortality than the patients with EN.
\end{abstract}

\section{Introduction}

According to the definition from the year 1979 , determined by Berg and Garlington, bacterial translocation (BT) is a migration of microorganisms naturally present in the gastrointestinal tract, and their toxins, from the intestinal lumen to mesenteric lymph nodes, blood, and the abdominal organs [1]. The phenomenon of bacterial translocation was suggested in year 1891 in the works of Fraenkel. However, it was the experience of Arnold and Brody who, on animals, confirmed the harmfulness of this effect. Crohn's disease, neutropae- nia, haemorrhagic shock, and necrotising enterocolitis - these are just some examples of the diseases associated with the process of translocation [2]. Bacterial translocation can, through the release of a series of inflammatory mediators, lead to local inflammation and the potential increase in intestinal permeability. This in turn can lead to systemic infection and multiple organ failure (MOF) - the syndrome that is the leading cause of death in the intensive care unit (ICU) [3].

The bacterial translocation process can take place through the vascular channels and/or lymphatic ones 
or by direct penetration of microorganisms through the intestinal wall. There is also a possibility of regressive bacterial migration to the lungs [4]. There are many factors affecting the appearance of bacterial translocation. The main ones are: trauma/injury, shock, immunosuppression, ischaemia, burns, use of antibiotics affecting the composition of the natural gastrointestinal microflora, irritation of the peritoneum, and intestinal obstruction [5].

A group of patients who have extremely high risk of bacterial translocation are those from the ICU. These are patients in critical condition, who have a direct threat to their life. Their condition is changing very rapidly; therefore, systematic monitoring of these patients is necessary [6]. Under the impact of an injury the body goes through a series of hormonal and metabolic changes caused by activation of the axis: the hypothalamus-pituitary glands [7]. The major change is the centralisation of the blood circulation, leading to decreased blood flow and distribution of oxygen through the kidney and the gastrointestinal tract. This leads to ischaemia of intestinal mucosa, resulting in changes in their histological structure. Depending on the duration of ischemia the structure of microvilli may vary including necrosis [8].

A very important factor affecting the condition of patients from the intensive care unit, as well as the condition of the gastrointestinal tract, is appropriate nutrition. However, these patients often are not able to eat meals without assistance. This situation is caused by accompanying symptoms such as consciousness disorders, and associated symptoms such as nausea, anorexia, and invasive treatment - intubation and sedation. There are two methods of nutritional treatment of these patients: enteral nutrition and parenteral (intravenous). For proper functioning of the intestine the body needs not only blood and oxygen, but also nutrients that provide energetic compounds [9]. A deficiency or lack of nutritional therapy leads to changes in the structure of the villi, which in turn can lead to systemic bacteraemia [5]. Enteral nutrition is now the preferred form of nutritional support of critically ill patients. It results not only from the lower costs of its use. Enteral nutrition prevents hypercatabolism, nourishes the intestinal mucosa, and increases the integrity of the intestinal barrier. According to the guidelines of the European Society for Clinical Nutrition and Metabolism (ESPEN) from 2006, it should be implemented if it is anticipated that the patient within three days in the hospital will not be able to achieve full oral feeding. In this case, within $24 \mathrm{~h}$, enteral nutrition should be implemented. Only when this is impossible to achieve, or contraindicated - as in the case of obstruction, lack of gastrointestinal function, or the abundantly secreting fistulas - should an alternative method of nutrition be used [10].

\section{Aim}

The aim of this study was to analyse the influence of enteral and parenteral nutrition on the bacteraemia caused by gastrointestinal pathogen occurrence.

\section{Material and methods}

A retrospective analysis of the medical documentation of 254 patients from the Anaesthesiology and Intensive Care Unit from the years 2009-2011 was made. The study group consisted of 112 women and 142 men. The age of patients was varied and ranged from 17 to 101 years. Mean age was 66 years. Number of organ failures on average was 2 (from 1 to more than 4). APACHE II scale at admission ranged from 4 to 61 points, and the average was 26 points. Fifty-four patients underwent surgery, which was equal to $21 \%$ of the respondents. Hospital stay was associated with death in 56 (22\%) patients. Seventy-one patients were fed enterally, 119 in a mixed way, and 64 patients were fed parenterally.

In cooperation with a clinical microbiologist, the patients' microbiological tests were analysed, assessing the presence of bacteraemia or sepsis pathogens originating from the gastrointestinal tract. Patients were divided into two groups according to the method of nutrition at the time of bacteraemia occurrence. The first group consisted of patients fed enterally (constant infusion, $20 \mathrm{~h}$ a day industrial diet) and in a mixed way; this group consisted of 29 patients $(n 1=29)$. Patients from the second group were parenterally fed. This group consisted of 23 people $(n 2=23)$. The composition of mixtures for parenteral nutrition was determined in each case individually and in subsequent days of feeding modified according to the metabolic needs and based on the results of laboratory tests. The infusion of parenteral nutrition in the first days lasted $24 \mathrm{~h}$ a day. The volume of the mixture for parenteral nutrition was determined on the basis of the daily urine and fluid balance of the patient.

Ethical approval for the retrospective study was provided by the Ethics Committee of the Collegium Medicum in Bydgoszcz. Data were collected in accordance with the ethical standards of the ethics committees.

\section{Results}

Among 254 patients, in 56 the presence of gastrointestinal pathogens in blood was found. In collaboration with a clinical microbiologist it was determined that 52 of the 56 reported cases concerned certain infections. The remaining four cases involved probable and possible infections. Of the 52 patients, 29 revealed the 
presence of pathogens during the enteral nutrition and 23 during parenteral nutrition.

The average length of stay by the time of bacteraemia occurrence was, among the first group, 14 days (range: $1-34)$, and in the second group it was 12.69 days (range: $1-74$ ).

The mean residence time without enteral nutrition in the first group was 3.5 days (range: 1-9). In the second group it was 12 days (range: $1-74$ ). In the first group bacteraemia were found after 10.86 days on average from the start of enteral nutrition.

However, much longer stay in the ICU and increased higher mortality in patients fed only parenterally was observed. These patients were on the ward for 37 days (range: 2-150) on average, while patients fed enterally and in a mixed way stayed in the ICU for 25 days (range: 3-88) on average. Deaths occurred more frequently in the second group; within parenterally fed patients mortality was about $56 \%$. Thirteen out of 23 patients included in this group died. In the first group the death rate was lower - mortality was 34\%; ten out of 29 people died.

\section{Discussion}

In the human gastrointestinal tract there are a set of microorganisms specific to them individual ecosystem. These microbes divide into commensal bacteria - suitable for the host, and relatively pathogenic microorganisms. Under normal conditions - when the person is healthy - there exists a balance between these bacteria and the host. However, in the case of reduced immunity, immunosuppression, or the disruption of microflora balance (for example by antibiotics usage) relatively pathogenic microorganisms can lead to opportunistic infection in the host [11].

The human digestive system is not just a set of organs responsible for digestion and absorption, but also an important immune centre of the body. An adequate protection of mucous membranes ensures a funtioning mucosal immune system (gut associated lymphatic tissue - GALT). A lack of nutrients for enterocytes and colonocytes negatively affects the morphology of the cells as well as their function. That leads to disturbances in the intestinal barrier and reduces the stimulation of the immune response of the GALT [12]. In the case of critically ill patients, even short-term starvation causes histopathological changes in the intestinal epithelium reduction of the villi and reduction of enzyme activity. This is confirmed by Hernández's et al. study, in which fifteen critically ill persons did not have the enteral feeding for four days on average. This led to atrophy of the intestinal mucosa [13]. Similar results were obtained in the study by Buchman et al. with parenteral nutrition. After 3 weeks the structure of the patients' intestinal villi changed [14].

Unlike parenteral nutrition, enteral nutrition has a beneficial effect on the gastrointestinal tract. It stimulates natural peristaltic movements and the function of nutrient digestion and absorption. Enzymes as well as intestinal hormones are released, thanks to which the process of disappearance of the intestinal villi becomes inhibited [10]. Intestinal epithelial cells are fed, which strengthens the mucosal immune system. Moreover, the effect of villi nutrition decreases the permeability of these cells to pathogens and their metabolites [15]. This prevents the occurrence of bacterial translocation and subsequent complications [16].

In our study, infections with gastrointestinal pathogens occurred in 56 patients out of 256 tested people. Among 52 patients, sure translocations occurred in 29 (56\%) patients fed enterally and in 23 (44\%) patients fed only parenterally. In this respect, the groups did not differ significantly between each other. Different results were obtained by Wildhaber et al. The mice that they examined were fed for seven days enterally (group 1), parenterally (group 2), and in a mixed way (group 3). Bacterial translocation occurred more frequently in mice that lacked the enteral nutrition [17]. Similar conclusions were obtained by Hadfield et al. They tested 24 critically ill patients. They divided them into two groups: the first group received enteral nutrition and the second one - parenteral. On the day of admission and on the third day of the hospital stay - after the admission of nutritional therapy - intestinal permeability was examined. The authors concluded that the enteral feeding - in contrast to parenteral feeding - favours maintaining the intestinal barrier [18]. Both, animal and humans studies, confirm the beneficial effect of enteral nutrition on the integrity of the mucosa.

In our material significantly longer ICU stay and higher mortality among patients fed only parenterally at the time of bacteraemia compared to patients fed enterally and in a mixed way was observed. In the first group the ICU stay lasted an average 24 days (range: $3-88$ ), while in the second group it was 39 days (range: $2-150$ ). Mortality in the second group was $56 \%$ (13 of 23 patients died), whereas in the first group 10 of 29 patients died (34\%).

Similar results were obtained by Chang et al. in their research. They chose two comparable groups of patients, from which the first one was fed in an enteral way and the second one in parenteral way. Despite the lack of statistical differences between the groups of patients, lower mortality in patients fed enterally was reported. Mortality in the groups was $25 \%$ in the first group and $51 \%$ in the second group [19]. Chang et al. 
are not the only scientists who have come to these conclusions. Demeyer et al. gave a retrospective analysis of sedated patients from the ICU. They compared a group of parenterally fed patients (first group) with those who were on enteral nutrition (second group). The results showed a significantly lower mortality in patients fed enterally. Mortality was 35\% in the first group and $24 \%$ in the second group [20].

\section{Conclusions}

In the analysed group the EN and the length of the absence of this type of feeding did not affect the bacteraemia with pathogens from the gastrointestinal tract. However, patients fed only parenterally who had diagnosed bacteraemia required a longer stay in the ICU, also had a higher mortality rate compared to patients with EN.

\section{Conflict of interest}

The authors declare no conflict of interest.

\section{References}

1. Berg RD. Bacterial translocation from the gastrointestinal tract. Adv Exp Med Biol 1999; 473: 11-30.

2. Wesley AJ. Bacterial translocation during enteral and parenteral nutrition. Proc Nutr Soc 1998; 57: 389-93.

3. Swank GM, Deitch EA. Role of the gut in multiple organ failure: bacterial translocation and permeability changes. World I Surg 1996; 20: 411-7.

4. Wiest R, Rath HC. Bacterial translocation in the gut. Best Pract Resh Clin Gastroenterol 2003; 17: 397-425.

5. Baue AE. The role of the gut in the development of multiple organ dysfunction in cardiothoracic patients. Ann Thorac Surg 1993; 55: 822-9.

6. Kübler A. Organizacja i podstawy funkcjonowania oddziałów intensywnej terapii. In: Anestezjologia kliniczna z elementami intensywnej terapii i leczenia bólu. Mayzner-Zawadzka E (ed.). Wyd. Lekarskie PZWL, Warsaw 2009; 2: 849-58.

7. Ciesielski L, Łupiński S. Pourazowe zaburzenia metabolizmu. In: Kompendium żywienia ciężko chorych. Wyd. Nakł. Kutnowskich Zakładów Farmaceutycznych „Polfa”, Lodz 1990; 7-32.

8. Swank GM, Deitch EA. Role of the gut in multiple organ failure: bacterial translocation and permeability changes. World I Surg 1996; 20: 411-7.

9. Van der Hulst RR, Von Meyenfeldt MF, Van Kreel BK, et al. Gut permeability, intestinal morphology, and nutritional depletion. Nutrition 1998; 14: 1-6.

10. Kreymann KG, Berger MM, Deutz NEP, et al. ESPEN Guidelines on enteral nutrition: intensive care. Clin Nutr 2006; 25: 210-23.

11. Keller JS. Trawienie i wchłanianie składników odżywczych w przewodzie pokarmowym. In: Podstawy fizjologii żywienia człowieka. Kiryjow J (ed.). Wyd. SGGW, Warsaw 2000; 119-64.

12. Górska S, Jarząb A, Gamian A. Bakterie probiotyczne w przewodzie pokarmowym człowieka jako czynnik stymulujący układ odpornościowy. Postepy Hig Med Dosw 2009; 63: 653-67.
13. Hernández G, Velasco N, Wainstein C, et al. Gut mucosal atrophy after a short enteral fasting period in critically ill patients. J Crit Care 1999; 14: 73-7.

14. Buchman AL, Moukarzel AA, Bhuta S, et al. Parenteral nutrition is associated with intestinal morphologic and functional changes in humans. JPEN 1995; 19: 453-60.

15. Lochs $\mathrm{H}$, Dejong $\mathrm{C}$, Hammarqvist $\mathrm{F}$, et al. ESPEN guidelines on enteral nutrition: gastroenterology. Clin Nutr 2006; 25: 260-74.

16. Farhadi A, Banan A, Fields J, Keshavarzian A. Intestinal barrier: an interface between health and disease. J Gastroenterol Hepatol 2003; 18: 479-97.

17. Wildhaber BE, Yang H, Spencer AU, et al. Lack of enteral nutrition: effects on the intestinal immune system. J Surg Res 2005; 123: 8-16.

18. Hadfield RJ, Sinclair DG, Houldsworth PE, Evans TW. Effects of enteral and parenteral nutrition on gut mucosal permeability in the critically ill. Am J Respir Crit Care Med 1995; 152: 1545-8.

19. Chang RW, Jacobs S, Lee B. Gastrointestinal dysfunction among intensive care unit patients. Crit Care Med 1987; 15: 909-14.

20. Demeyer I, Bataillie K, Baute I. Long-term sedation in the ICU: enteral versus parenteral feeding. Clin Intens Care 1994; 5: $13-6$.

Received: 25.04 .2015

Accepted: 5.05 .2015 